\section{INHIBITION BY DOXORUBICIN OF HUMAN IMMUNO-DEFICIENCY VIRUS (HIV) INFECTION AND REPLICATION IN VITRO}

\author{
Hideki NaKashima \\ and NAOKI YAMAMOTO
}

Department of Virology and Parasitology, Yamaguchi University School of Medicine, 1144 Kogushi, Ube, Yamaguchi 755, Japan

\section{YOSHIO INOUYE and SHOSHIRo NAKAMURA}

Institute of Pharmaceutical Sciences, Hiroshima University School of Medicine, 1-2-3 Kasumi, Minami-ku, Hiroshima 734, Japan

(Received for publication August 25, 1986)

Human immuno-deficiency virus (HIV) also known as human T-lymphotropic virus type III (HTLV-III) ${ }^{1 /} /$ lymphadenopathy-associated virus $(\mathrm{LAV})^{2)}$ is a newly recognized retrovirus and thought to be the causative agent of the acquired immune deficiency syndrome (AIDS) and AIDSrelated complex $(\mathrm{ARC})^{3,4)}$. Inhibitors of reverse transcriptase, whose activity is essential for the replication of retroviruses, might be candidates for the chemotherapy of HIV infections. Many compounds have been reported as inhibitors of reverse transcriptase e.g. suramin ${ }^{5)}$ and HPA $23^{6)}$, however their clinical efficacy has not been established.

An initial mass survey on a number of antibiotics was carried out in a search for inhibitors of avian myeloblastosis virus (AMV)-reverse transcriptase. Enzyme activity was measured by the incorporation of $\left[{ }^{3} \mathrm{H}\right] \mathrm{TTP}$ into a high molecular fraction using poly(rA)-oligo(dT $)_{12 \sim 18}$ as template-primer in the presence of either 10 or $40 \mu \mathrm{g} / \mathrm{ml}$ antibiotic ${ }^{7)}$. Among the potent enzyme inhibitors found, only those of low cytotoxicity have been further tested for their effects on the in vitro replication of HIV using the HTLV-Icarrying cell line, MT-4 ${ }^{8)}$. One of the virus strains of HIV, HTLV-III was obtained from the culture supernatant of Molt-4/HTLV-III ${ }^{\text {) }}$. MT4 cells were maintained in RPMI 1640 medium supplemented with $10 \%$ fetal calf serum (FCS), $100 \mathrm{IU} / \mathrm{ml}$ of benzylpenicillin and $100 \mu \mathrm{g} / \mathrm{ml}$ of streptomycin at $37^{\circ} \mathrm{C}$ in a $\mathrm{CO}_{2}$ incubator. MT-4 cells were exposed to virus preparations at a multiplicity of infection (MOI) of 0.002 for 1 hour at $37^{\circ} \mathrm{C}$. After infection, the cells were washed and resuspended in fresh medium to give a concentration of $3 \times 10^{5}$ cells $/ \mathrm{ml}$. This cell suspension was then cultured in the presence or absence of various concentrations of doxorubicin in a $\mathrm{CO}_{2}$ incubator. Half of each culture medium was changed every 3 days. The bio-assay system using MT-4 cells for studying HIV infection was developed by HARADA et al. ${ }^{8}$. Inhibitory effects of sakyomicin $\mathrm{A}^{10)}$, recombinant human interferon gamma ${ }^{1.12}$ and $3^{\prime}$-azido-3'-deoxythymidine $(A Z T)^{12)}$ on HIV infection were recognized using this assay system.

Approximately 150 antibiotics classified into various groups have been tested for their effects on AMV-reverse transcriptase. Among anthracyclines included in our screening, doxorubicin, daunorubicin and aclarubicin were chosen for the further investigation and the results are given in this note. Doxorubicin and daunorubicin were potent inhibitors of reverse transcriptase. The $\mathrm{IC}_{50}$ 's against $\mathrm{L} 5178 \mathrm{Y}$ cells were $0.04 \mu \mathrm{g} / \mathrm{ml}$ for daunorubicin and $0.49 \mu \mathrm{g} / \mathrm{ml}$ for doxorubicin. Therefore, daunorubicin was relatively toxic to the cells. Though no marked inhibition of reverse transcriptase was observed by aclarubicin, it was the most cytotoxic of the anthracycline group $\left(\mathrm{IC}_{50}\right.$ against $\mathrm{L} 5178 \mathrm{Y}$ cells: $\left.0.004 \mu \mathrm{g} / \mathrm{ml}\right)$ (Table 1). In view of the inhibition of reverse transcriptase and cytotoxicity, we further studied doxorubicin and its ability to inhibit HIV infection in MT-4 cells. The cytotoxity of doxorubicin against HIV-uninfected MT-4 cells, and effects of this chemical on the growth and viability of the cells as well as virus antigen expression induced by HIV infection were assayed on the 3rd and 6th days after infection. Although doxorubicin was cytotoxic against MT-4 cells at concentrations of 10 and $1.0 \mu \mathrm{g} / \mathrm{ml}$, no significant difference was observed in cell growth be-

Table 1. Inhibition by anthracycline antibiotics of reverse transcriptase from avian myeloblastosis virus.

\begin{tabular}{lccc}
\hline \multirow{2}{*}{ Chemical } & \multicolumn{2}{c}{ Inhibition (\%) } & IC $_{50}$ \\
\cline { 2 - 3 } & $40 \mu \mathrm{g} / \mathrm{ml}$ & $10 \mu \mathrm{g} / \mathrm{ml}$ & \\
\hline Doxorubicin & 70.4 & 29.8 & 0.49 \\
Daunorubicin & 55.5 & 13.9 & 0.04 \\
Aclarubicin & 29.3 & 15.3 & 0.004 \\
\hline
\end{tabular}


Fig. 1. Inhibitory effect of doxorubicin on cytopathic effects of HIV and the expression of HIV-specific antigens.

MT-4 cells (A and B) and HIV infected MT-4 cells (C, D, E and F) were cultured in the presence or absence of various concentrations of doxorubicin. The cells were infected with virus at a multiplicity of infection of 0.002 and incubated for 1 hour at $37^{\circ} \mathrm{C}$. After adsorption, infected cells were washed and resuspended in fresh medium to give a concentration of $3 \times 10^{5}$ cells $/ \mathrm{ml}$. The viable cells with or without HIV infection were determined by trypan blue dye exclusion method 3 days ( $\mathrm{A}$ and $\mathrm{C}$ ) and 6 days (B and D) after culture. For the expression of HIV-specific antigens, indirect immunofluorescence (IF) was applied ${ }^{11 \sim 13}$. More than 500 cells were counted and frequency of IF-positive cells was calculated 3 days (E) and 6 days $(F)$ after infection.
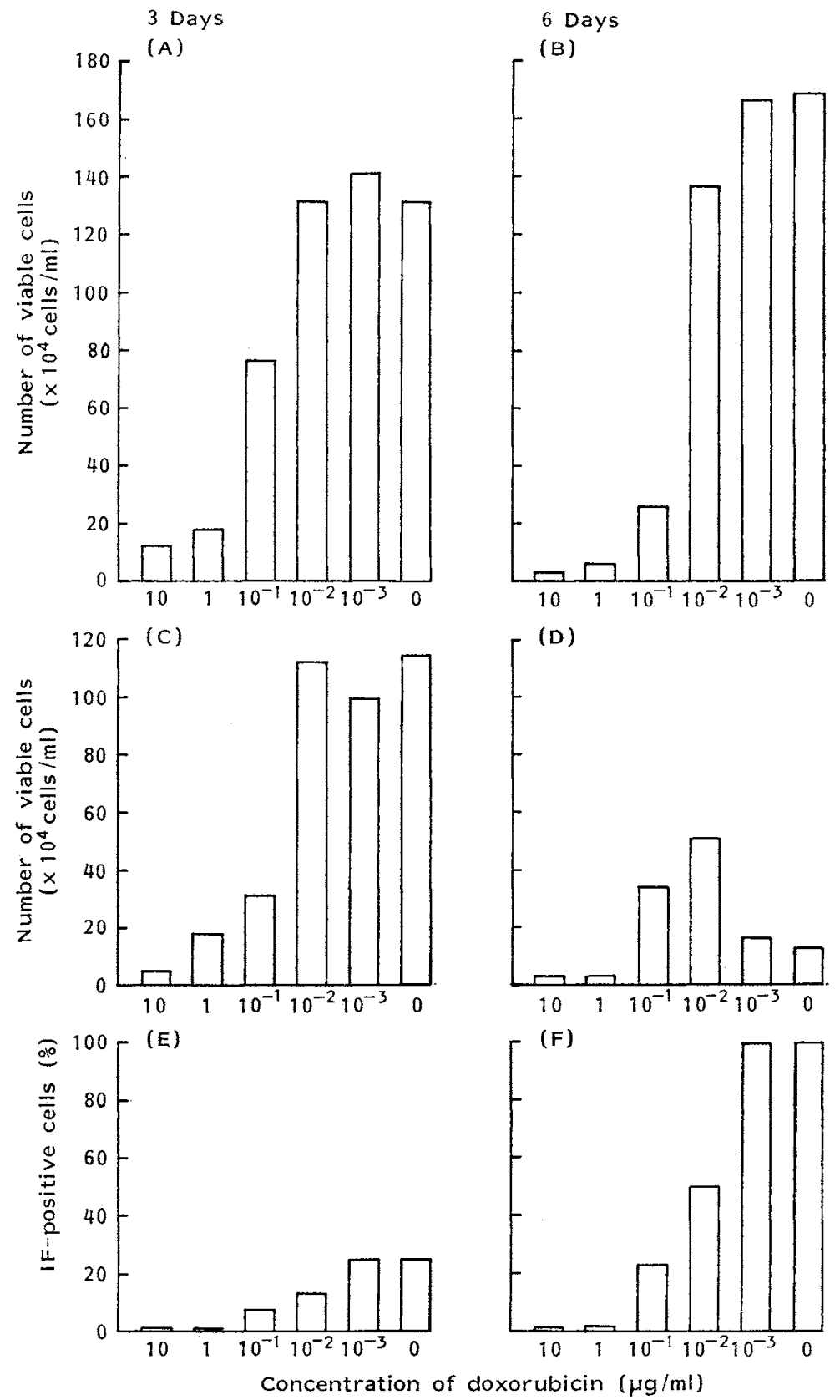
tween MT-4 cell cultures treated with 0.01 or $0.001 \mu \mathrm{g} / \mathrm{ml}$ of doxorubicin and drug free controls (Fig. 1A and 1B). For example, the number of viable cells in cell cultures treated with $10,1.0$, $0.1,0.01$ and $0.001 \mu \mathrm{g} / \mathrm{ml}$ of doxorubicin were $3,5,25,137$ and $167 \times 10^{4}$ cells $/ \mathrm{ml}$, respectively after 6 days culture. At the same time it was $170 \times 10^{4} \mathrm{cells} / \mathrm{ml}$ in doxorubicin free control cultures. On the 6 th day after infection, although the number of living cells in the culture without doxorubicin was $11 \times 10^{4} \mathrm{cells} / \mathrm{ml}$, those in the cultures with 0.1 and $0.01 \mu \mathrm{g} / \mathrm{ml}$ of this drug were $32 \times 10^{4}$ and $50 \times 10^{4}$ cells $/ \mathrm{ml}$, respectively (Fig. 1D). In accordance with this observation, induction of HIV-specific antigens was also inhibited by the drug (Fig. 1E and $1 F$ ). On the 6 th day after infection, frequencies of antigen-positive cells were $24 \%$ and $51 \%$ in the infected MT-4 cells treated with 0.1 and $0.01 \mu \mathrm{g} / \mathrm{ml}$ of the chemical, respectively. In control cultures as well as those treated with $0.001 \mu \mathrm{g} / \mathrm{ml}$ of doxorubicin $99 \%$ of the cells expressed viral antigens. These data show that doxorubicin inhibits the cytopathic effect of HIV and appearance of virus-specific antigens in MT-4 cells at concentrations of 0.1 and $0.01 \mu \mathrm{g} / \mathrm{ml}$.

To determine the inhibitory effect of doxorubicin on HIV replication quantitatively, a plaque forming assay was performed. The supernatants of HIV infected MT-4 cells which were cultured with various concentrations of drug for 4 days were subjected to a plaque forming assay ${ }^{8,13)}$. As shown in Table 2, the supernatants from cell cultures treated with $0.1,0.01$ and $0.001 \mu \mathrm{g} / \mathrm{ml}$ of doxorubicin showed virus titers of $38.7,38.7$ and $54.7 \times 10^{3}$ plaque forming unit $(\mathrm{PFU}) / \mathrm{ml}$,

Table 2. Effect of doxorubicin on virus replication in HTLV-III infected MT-4 cells.

\begin{tabular}{cc}
\hline $\begin{array}{c}\text { Doxorubicin } \\
(\mu \mathrm{g} / \mathrm{ml})\end{array}$ & $\begin{array}{c}\text { Released virus particles } \\
\left(\times 10^{3} \mathrm{PFU} / \mathrm{ml}\right)\end{array}$ \\
\hline 10 & 0 \\
1 & $0.3 \pm 0.6^{\mathrm{b}}$ \\
0.1 & $38.7 \pm 4.2$ \\
0.01 & $38.7 \pm 6.1$ \\
0.001 & $54.7 \pm 10.3$ \\
0 & $66.7 \pm 7.6$ \\
\hline
\end{tabular}

a Virus preparations were obtained from the supernatant of HTLV-III infected MT-4 cells cultured with doxorubicin for 4 days.

b Experiments were carried out in triplicate. Results were represent as the mean $t$ SD . respectively. Under the same condition the virus preparation from HIV infected MT-4 cells cultured without drug gave $66.7 \times 10^{3} \mathrm{PFU} / \mathrm{ml}$ (Table 2). In cell cultures treated with the higher concentrations of doxorubicin $(10$ and $1.0 \mu \mathrm{g} / \mathrm{ml})$, virus antigens were not induced and plaque formation was completely suppressed. However, these effects observed at the higher concentrations appeared to result from the cytotoxicity of doxorubicin against host cells and not on the viruses.

The experimental results described above suggest that doxorubicin inhibits the infectivity and replication of HIV at the concentrations of $0.01 \sim$ $0.1 \mu \mathrm{g} / \mathrm{ml}$ and might be used as an antiviral agent for AIDS and ARC.

\section{Acknowledgment}

The authors wish to thank Miss C. IsHIDA for helpful assistance. Part of this work was supported by a Grant-in-Aids for Cancer Research from Ministry of Education, Science and Culture, and Health and Welfare of Japan.

\section{References}

1) Popovic, M.; M. G. Sarngadharan, E. Read \& R. C. Gallo: Detection, isolation, and continuous production of cytopathic retroviruses (HTLV-III) from patients with AIDS and preAIDS. Science 224: 497 500, 1984

2) Barré-Sinoussi, F.; J. C. Chermann, F. Rey, M. T. Nugeyre, S. Chamaret, J. Gruest, C. Dauguet, C. Axler-Blin, F. Vézinet-Brun, C. Rouzioux, W. Rozenbaum \& L. MonTAGNIER: Isolation of a T-lymphotropic retrovirus from a patient at risk for acquired immune deficiency syndrome (AIDS). Science 220: 868 871, 1983

3) Broder, S. \& R.C. Gallo: A pathogenic retrovirus (HTLV-III) linked to AIDS. N. Eng1. J. Med. 311: 1292 1297, 1984

4) KlatzmanN, D.; F. Barré-Sinoussi, M. T. Nugeyre, C. Dauguet, E. Vilmer, C. Griscelli, F. Brun-Vezinet, C. Rouzioux, J. C. Gluckman, J.-C. Chermann \& L. MONTAGNIER: Selective tropism of lymphadenopathy associated virus (LAV) for helperinducer $T$ lymphocytes. Science 225: 59 63, 1984

5) Mitsuya, H.; M. Popovic, R. Yarchoan, S. Matsushita, R. C. Gallo \& S. Broder: Suramin protection of $T$ cells in vitro against infectivity and cytopathic effect of HTLV-III. Science 226: 172 174, 1984 
6) Rozenbaum, W.; D. Dormont, B. Spire, E. Vilmer, M. GenTILINI, C. Griscelli, L. MONTAGNIER, F. BARRE-Sinoussi \& J. C. ChERMANN: Antimoniotungstate (HPA 23) treatment of three patients with AIDS and one with prodrome. Lancet 1985-I: 450 451, 1985

7) Hanajima, S.; K. Ishimaru, K. Sakano, S. K. ROY, Y. INOUYE \& S. NAKAMURA: Inhibition of reverse transcriptase by limocrocin. J. Antibiotics 30: 803 805, 1985

8) Harada, S.; Y. Koyanagi \& N. Yamamoto: Infection of HTLV-III/LAV in HTLV-I-carrying cells MT-2 and MT-4 and application in a plaque assay. Science 229: 563 566, 1985

9) KoyanaGi, Y.; S. Harada \& N. Yamamoto: Establishment of a high production system for AIDS retroviruses with a human T-leukemic cell line Molt-4. Cancer Lett. 30: 299 310, 1986

10) Tanaka, N.; T. OKabe, N. Tanaka, Y. TAKe, Y. INOUYE, S. NaKamura, H. NaKashuma \&
N. Yamamoto: Inhibition by sakyomicin A of avian myeloblastosis virus reverse transcriptase and proliferation of AIDS-associated virus (HTLV-III/LAV). Jpn. J. Cancer Res. (Gann) 77: 324 326, 1986

11) Nakashima, H.; T. Yoshida, S. Harada \& N. YAMAMOTO: Recombinant human interferon gamma suppressed HTLV-III replication in vitro. Int. J. Cancer 38: 433 436, 1986

12) Nakashima, H.; T. Matsut, S. Harada, N. Kobayashi, A. Matsuda, T. Ueda \& N. YAMAMOTO: Inhibition of replication and cytopathic effect of HTLV-III/LAV by 3'-azido-3'deoxythymidine in vitro. Antimicrob. Agents Chemother. 30: 933 937, 1986

13) Nakashima, H.; Y. Koyanagi, S. Harada \& N. YAMAMOTO: Quantitative evaluations of the effect of UV irradiation on the infectivity of HTLV-III (AIDS virus) with HTLV-Icarrying cell line, MT-4. J. Invest. Dermatol. 87: 239 243, 1986 